\title{
ENQUIRY PEDAGOGY IN TEACHING TITRATIONS WITH USING NATURAL INDICATOR
}

\author{
UdanKusmawan,Afnidar, Srihamda, and Deetje Sunarsih \\ Chemistry Education Department, Universitas Terbuka, Jakarta
}

\begin{abstract}
This article draws on community services led by Lectures from the Department of Chemistry of Terbuka University (UT), Indonesia. The activities have involved teachers of chemistry in Tigaraksa High Schools. All the teachers took active participations in guidedlaboratory activities through practicing SSCS Instructional model. This model constitutes an enquiry method encompassing four scientific phases of Search, Solve, Create and Share. The SSCS model was introduced to the teachers prior to their practicing laboratory activities. Through the Search phase, a video was presented to teachers showing a lesson on how a red cabbage can be used as a natural indicator for acids-bases titration processes. The teachers continuedon moving forwards onto the other phases while teaching the topic of Titrations. The result indicated that in general (over $71 \%$ ) the teachers consented that this method has been an effective vehicle to bring the environment into in-laboratory activities while teaching Titration topic of using natural materials. Through the lab activities, it was found that red cabbage is a $\mathrm{pH}$ indicator indicated by the shifting colors from red (at $\mathrm{pH}$ of 2) to purple (at $\mathrm{pH}$ of 3-6) and stop at blue color (at $\mathrm{pH}$ of 7 9 ). The color of Purple comes from Sianidin including anthocyanin aglyconeanthocyanidins, which is formed through hydrolyzed with acid. Finally, it was found that this enquiry method of SSCS has become an effective model for guiding teachers in integrating the environment into laboratory activities while teaching the topic of Titration.
\end{abstract}

Keywords:Natural indicator, environmental, group indicator, SSCS instructional model

\section{Introduction}

Issues on how teachers working out on students' laboratory activities have long been in discussionby teachers, especially by those who join Teachers' Group on Subject Matters (read in Indonesian context as Musyawarah Guru MataPelajaran - MGMP). Frequently, teachers realize that they do not have sufficient skills in organizing lab activities for students in connection to their environmental actions. Some teachers are likely to complain the "not enough" infrastructure to conduct practical works on environmental action for their students.

Through this articel, we assume that, teachers should be able to manage creative laboratory activities without demanding on fulfillment of laboratory facilities, which are usually expensive and risky. Instead, the teachers need to find the best method such as the stated teachers' demand, which was, however, considred as the way to improve the quality of environment- based activities for students to learning and experiencing the learning of science.

Teachers' professional development in improving the quality of laboratory activities in using simple materials that are available in their surrounding environment may strengthen students' motivation whose interest in doing such lab-base chemical laboratory processes is poor. Regardless the quality of schools, the teachers can certainly carry out chemical lab-based activities with using simple materials from the environment. In this case, teachers can foster the quality of student learning with high abilities in handling practical works.

To achieve these conditions, the first issue is how to improve teachers' skill and creativity in developing chemical lab with using the available and simple environment materials. The second one is how the

Corresponding Author: UdanKusmawan/udan@ecampus.ut.ac.id 
teachers can facilitate chemistry learning through usingonline resources.

\section{Literature Review}

\section{Natural indicators}

Todays, synthetic indicators are the choice of acid-base titrations. But due to environmental pollution, availability and cost, the search for natural compounds as an acid-base indicator has been started. Many plants, for example, contain their own indicators, including turmeric, red cabbage juice and beetroot juice are three good examples. Other examples are tea and red grape juice. In some places, Hydrangea flowers are pavorite for this indicator. It gives different colours depending on whether the soil is acid or alkali. In acid soil, they are blue and in alkaline soil, they are red.

\begin{tabular}{|c|c|c|c|}
\hline Indicator & $\begin{array}{c}\text { Colour in acid } \\
(\mathbf{p H}<\mathbf{7})\end{array}$ & $\begin{array}{c}\text { Colour at } \\
\mathbf{p H = 7}\end{array}$ & $\begin{array}{c}\text { Colour in base } \\
(\mathbf{p H}>\mathbf{7})\end{array}$ \\
\hline Red cabbage water & red, pink & purple & blue, green, yellow \\
\hline Red onion water & red & violet & green \\
\hline Turmeric water & yellow & yellow & red \\
\hline Phenolphthalein & colourless & colourless & pink, red \\
\hline Bromothymol blue & yellow & green & blue \\
\hline Red litmus & red & red & blue \\
\hline Blue litmus & red & blue & blue \\
\hline Universal indicator & red, orange, yellow & green & Blue, violet, purple \\
\hline
\end{tabular}

Figure 1. Changing colours for several natural indicators

This natural indicator is easy to extract as well as easily available. Promising results were obtained when it was compared against standard synthetic indicators. Titration shows sharp color change at the equivalence point. The equivalence points obtained by the flowers extract coincide with the equivalence points obtained by standard indicators. These natural indicators are found to be a very useful, economical, simple, accurate and eco-friendly

\section{Red Cabbage}


One of the simple material that is available in the environment is Red Cabbage. This Red cabbage contains at least thirty-six of the 300 kinds of anthocyanin that play a role in a variety of red and blue

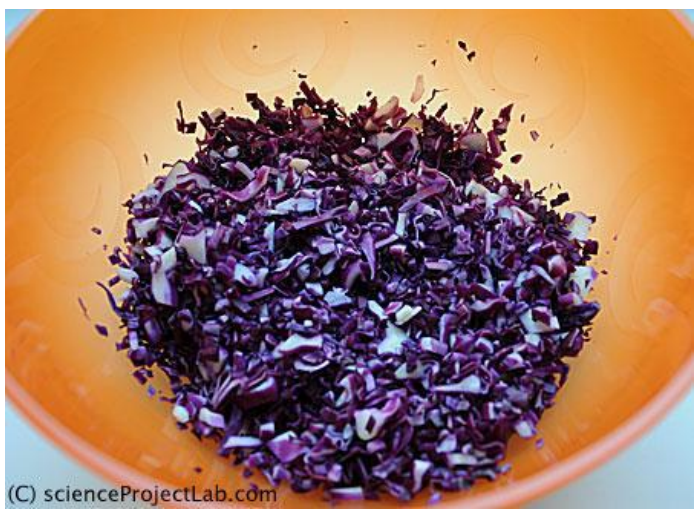

Figure 2. Chop red cabbage to extract the pigment.

colors in plants (Charronet. Al., 2007). Anthocyanins consist of several rings of carbon to hydrogen or hydroxyl groups attached. This allows the chemical formation of anthocyanin molecules to take two forms (in which one of the hydrogen atoms attached to the exterior and one not). As indicated in Figure 1, Acid material is characterized by having more of the hydrogen atoms $(\mathrm{H}+)$ of the hydroxyl group $(\mathrm{OH}-)$ so that when exposed to acid, anthocyanin hydrogen atoms captured and turned red. In alkaline conditions where there is no excess hydrogen atom, the molecule is the color that appears blue or green (Charron et. al., 2007), see Figure 2. The pigment molecules are stored in the cells of leaves of red cabbage. When exposed to heat during cooking, cells that contain anthocyanins open, causing the color pigments dissolved into the surrounding fluid. as indicated in Figure 3, this explains the color change directly in the cooking water red cabbage extract to produce a colorless liquid called cabbage (Charron et. Al., 2007), which can then be directly used as a natural indicator solution. The presence of anthocyanin cabbage can cause color changes to red (Ekasari, 2010).

Anthocyanin pigments in red cabbage, chemical anthocyanin derivatives single aromatic structure, namely sianidin, and all made from pigments sianidinpigments with the addition or subtraction of hydroxyl groups, methylation and glycosylation (Harborne 2005). Anthocyanins are compounds that are amphoteric, ie have the ability to react either with acids or with bases. In amedium acidicicred of anthocyanin, and in an alkaline medium turned into purple and blue (Man 1997).

The use of red cabbage as a $\mathrm{pH}$ indicator is based on the change in color from red at $\mathrm{pH} 2$ to purple at $\mathrm{pH}$ 3-6 and then a blue color around $\mathrm{pH}$ 7-9 which is an endpoint. Purple color comes from sianidin including anthocyanin which is aglyconeanthocyanidins that is formed when it is hydrolyzed with acid. Pelargonidinwhichorangecolor is caused by the hydroxyl groups less one than sianidin, while the blue color is generally caused by delfinidin which the hydroxyl groups less one than sianidin (Harborne, 2006). Therefore, it is possible to determine the $\mathrm{pH}$ of a solution based on the color change of anthocyanin pigments of red cabbage juice. The above figure 3 shows the range of colors that can be achieved with red cabbage in a wide range of $\mathrm{pH}$ (Agee, 2006).

\begin{tabular}{|c|c|c|c|c|c|c|}
\hline Colour & Pink & Red & Violet & Blue & $\begin{array}{c}\text { Bluish } \\
\text { green }\end{array}$ & $\begin{array}{c}\text { Greenish } \\
\text { yellow }\end{array}$ \\
\hline $\begin{array}{c}\text { Approximate } \\
\text { pH }\end{array}$ & 1 & 3 & $5-7$ & 8 & 9 & 11 \\
\hline Classification & \multicolumn{2}{|c|}{ acidic } & $\begin{array}{c}\text { acidic- } \\
\text { neutral }\end{array}$ & \multicolumn{3}{|c|}{ basic } \\
\hline
\end{tabular}

Figure 3. Changing colour for pigment in red cabbage 


\section{Method: SSCS as Method of Scientific community actions}

SSCS stands for Search, Solve, Create and Share.This is an instructional model originally for scientific teaching and learning. In this paper, this model is adapted as a metod of guiding teachers' activities through which the lecturers led and directed teachers' action on conducting practicum regarding environment-based activities while preparing thier adapted model of teaching to be applied in their classroom. This adapted model was intended as the output of the community service activities.

The SSCS has its premise that for a problem to be meaningful to a student, it needs to be identified and defined by the student and that students meaningfully learns problem-solving skills and scientific concepts. Many popular hands-on science activities, as traditionally implemented, fail to support inquirybased science instruction, because the activities direct teachers to terminate lessons prematurely. This paper presents a model describing one approach for extending seemingly limited hands-on activities into full-inquiry science lessons. The strategy involves (a) discrepant events to engage students in direct inquiry; (b) teacher-supported brainstorming activities to facilitate students in planning investigations; (c) effective written job performance aids to provide structure and support; (d) requirements that students provide a product of their research, which usually includes a class presentation and a graph; and (e) laboratory discussion and writing activities to facilitate students in reflecting on their activities and learning. Steps describing the model are shown in following table.

\begin{tabular}{|l|l|}
\hline Search & $\begin{array}{l}\text { Brainstorming to identify problem, generate a list of ideas to explore, put into } \\
\text { question format and focus on investigation }\end{array}$ \\
\hline Solve & $\begin{array}{l}\text { Generate and implement plans for finding a solution, develop critical and } \\
\text { creative thinking skills, form hypotheses, select the method for solving the } \\
\text { problem, collect data and analyse }\end{array}$ \\
\hline Create & $\begin{array}{l}\text { Student create a product in a small scale to the problem solution, reduce the } \\
\text { data to simpler levels of explanation, present the results as creatively as } \\
\text { possible such using charts, poster or model. }\end{array}$ \\
\hline Share & $\begin{array}{l}\text { Students communicate their findings, solution and conclusions with teacher } \\
\text { and students, articulate their thinking, receive feedback and evaluate the } \\
\text { solutions. }\end{array}$ \\
\hline
\end{tabular}

Preceding the actions, the lectures conducted short survey with four questions. The lecturers were asking the teachers to raise their hands for each question. The questions were about (1) Knowledge of teachers using the Internet in their schools, (2) Teachers' ability of downloading videos from the Internet, (3) Teachers' antuisasme on learning natural indicators, and (4) Video-discussion demonstration method that increases participants' interest, and saves time and efforts. Hereafter, along with community service actions, the lectures were firstly presenting video, retrieved from Youtube, demostrating the practicum of acid-base titration with using various natural indicators. We provide all the materials demonstrated in the Video. The teachers were grouped into 5, consisting 5-7 teachers each, while following the guidedactivities. At the end of activities, the teacher were required to develop teaching materials as they have replicated all activities they followed.

\section{Results and Discussions}

As indicated previously, the lectures were firstly presenting video, retrieved from Youtube, demostrating the practicum of acid-base titration with using various natural indicators. We provide all the materials demonstrated in the Video. The teachers were grouped into 5, consisting 5-7 teachers each. 


\section{Search phase}

This video presentation constitutes the first phase of the SCSS. Through this phase, to the teachers were introduced many literatures and links containing this similar information. Among the links introduced to the the teachers in this phase are as below containing examples of acid-base titration:

- Verificative activities on acid-base titration: https://www.youtube.com/watch?v=vajKeYQbX0w

- Practicum of acid-base titration conducted by SMA Assa'adah XI, Dubai: https://www.youtube.com/watch?v=V7iVytVYXD4

- Exam on acid-base titration: https://www.youtube.com/watch?v=ufZoJw331Dg

- https://www.youtube.com/watch?v=88JGuO5ENhU

- Exam preparation for acid-base titration: https://www.youtube.com/watch?v=wdIUhhKtDI4

- Extracting red cabbage for acid-base titration: https://www.youtube.com/watch?v=WzedPt $37 \mathrm{fc}$

- Red cabbage acid-base titration by SMP IHBS Jakarta: https://www.youtube.com/watch?v=zt2U6g0RYKI

Introducing the videos, the lectures were using power point presentation (PPt). The PPt contains information on title of activities, aims of the activities, activity phases of practicum, example links as listed above, and finally steps of the activities to be followed by the teachers. This way was to example the teachers as an appropriate methods to lead students in thier classes while teaching and learning acidbasetiration.

Throughout presenting the PPt, the lectures suggested that this way of teaching and learning must attract students' attention. This is alligned with Djamarah S.B., (2000) recommendation that demonstration methods was to confirm the intended real and actual processes which require understanding through activities, as well as movement. He further argued that demonstration methods strengthen learners' skills on how to observe movements or processes from the objects presented.

As mentioned, the lectures conducted a short survey with four questions before and after the teachers had been involved in Search phase. The lecturers were asking the teachers to raise their hands for each question. Results of the survey and its questions are described in Graph 1.

Based on information in the Graph, it is apparent that activities guided by the lecturers conducted during the Search phase have enabled to increase the four aspects of teachers' prior knowledge towards multimedia for education.

\section{Solve phase}

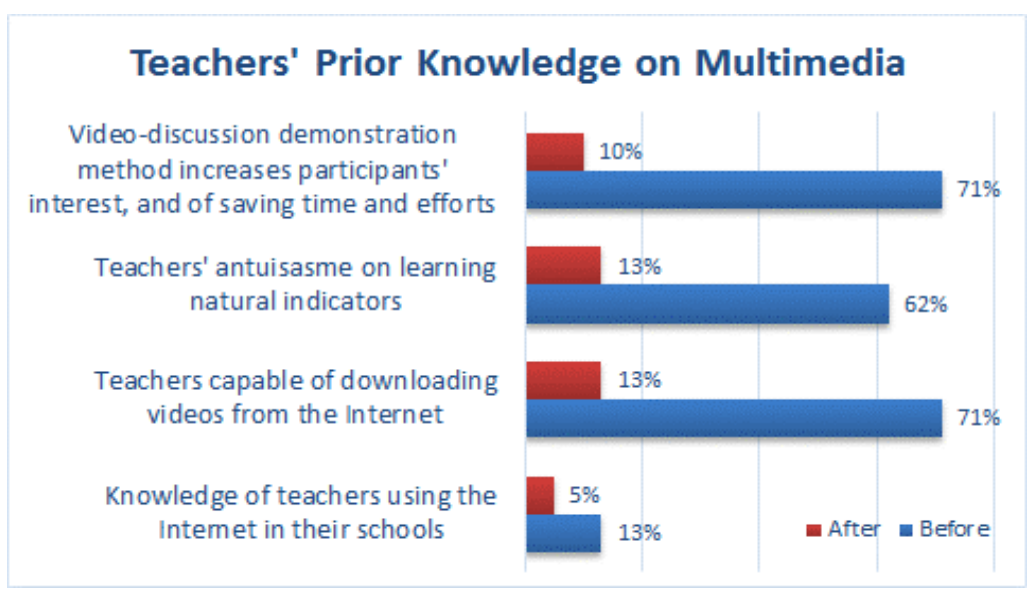

Graph 1. Inital survey to teachers 
As Hernandez \& Joe (2010) suggested, teaching chemistry with involvement of computer-based presentation helped learners strengthened thier interest, hence improved their understanding towards the concepts and principles presented. In this situation, it was intended that the teachers would replicate impementation strategies in their real classroom.

During this phase, the teachers in group generated and implemented plans for formulating teaching materials and strategies, developing critical and creative thinking skills to be captured from their students, and selecting media for presenting the materials appropriately to the methods defined. In addition, they were collecting and analysing data to enrich thier methods of teaching.

The group conducted discussion on the plans that needed to be fulfiled by all the teachers of the group. This phase was completed indpendently by all participants in two weeks. All the participants admitted that this way of collaborative works has strengthened thierexpereinces meaningfully, as indicated in the Graph 1 .

\section{Create phase}

Having the teachers in groups prepared all materials to be produced, independently, we were then discussed how all the materials were arraged and reported. This meeting was aimed at guiding all teachers to understand the reason why a report was to be created and how the report needed to be shared to other parties, including their students.

During this phase, having the teachers developed a report, they created a product in a small scale (including presentation materials), reduced the data to simpler levels of explanation, and presentation design of the results as creatively as possible such as using charts, and designed posters or models that might be better or inovative works developed from what have been learned from the lecturers.

Hadimiarso, Y. (1984) suggested that various media being used to facilitate learners' thinking, intention and motivation development might be subject to encourage the learners to learn. The existence of media to accompany verbal communication as frequently happen in lecturing might accomodate learners'undersnding as they visulize abstract concepts and transmit them into reality.

Finally, throughout this phase, the lecturer accompanied the teachers to devloped material presentations based on their report.

\section{Share phase}

Gagne dan Briggs (1979) argued that teaching and learning (instructional activities) should be a series of events (creation, events, conditions, etc.) that are deliberately designed to affect learners. Instruction or learning, on the other hand, is a system that aims to help the students' learning process, which contains a series of events planned and structured contents which influence and support the learners' learning processes.

Learning in this work can be defined as a process that requires the presentation of material activity and scientific attitude of the learners in learning a subject matter which has been determined based on the applicable curriculum.

Through this phase, all the teachers presented their materials in the mini seminar. Audiences of the seminar were all participants of the community services, including participating teachers and lecturers. The lecturers shared critiques and suggestions to improve their material and models. 


\section{Conclusion}

These community services haveevidently facilitated teachers with strategies to collaboratively manage thier environmental-based practicum and develop materials to be presented for their classroom purposes. The teachers have managed creative laboratory activities without demanding on fulfillment of laboratory facilities, which are usually expensive and risky. Having participated in these activities, the teachers have experienced a scientific method to improve the quality of environment-based activities for students to learning and experiencing the learning of science.

Teachers' professional development in improving the quality of laboratory activities in using simple materials that were available in their surrounding environment has strengthened students' motivation whose interest in doing such lab-base chemical laboratory processes is poor. Regardless the quality of schools, the teachers can certainly carry out chemical lab-based activities with using simple materials from the environment. In this case, teachers fostered the quality of learning with high abilities in handling practical works.

\section{Reference}

Ahmad Walid. 2015. mpd.blogspot.co.id/2015/09/sains-pembelajaran-dan-proses-berpikir.html.

AjiCaturMurdiono. 2010. Karaktrisasitrayek pH danSpektrumAbsorpsiKubisUngu(Brassica oleracea L). LaporanPenelitan, Yogyakarta: FMIPA UNY

CandraAjityasAnggitSaputra.

2010.KarakterisasiTrayekphdanSpektrukAbsorpsiEkstrakKubisUnguKering (Brassica oleracea) sebagaiIndikatorAlamiTitrasiAsamBasa, LaporanPenelitian, FMIPA UNY: Yogyakarta

Charron CS, Clevidence B, Britz SJ, Novotny JA. 2007. Effect of dose size on bioavailability of acylated and nonacylatedanthocyanins from red cabbage (Brassicaoleracea L. Var. capitata). In J Agric Food Chem 55:5354-62. Ekasari et al., 2010 Primary nutritional content of bio-flocs cultured with different organic carbon sources and salinity Hayati J Biosci, 17. pp. 125-130

Chigurupati, N., Saiki, L., Geyser, C., Dash, K.A.2002. Evaluation of Red Cabbage Dye as A Potential Natural Color for Pharmaceutical use, International of Journal Pharmaceutical 2002 July 25; 241(2): 293299

Day, R. A Jr., dan Underwood, A.L. 2002. AnalisisKimiaKuantitatif, Jakarta: Erlangga

DiyarSalahudin Ali. 2009. Identification of an Anthocyanin Compound from Strawberry Fruits then Using as An Indicator in Volumetric Analysis, Journal of Family Medicine, Vol 7 Issue 7

Fessenden, R. J. dan Fessenden, J. S. 1995. Kimia OrganikEdisiketigaJilidI (TerjemahanHendyanaPujaatmaka), Jakarta: Erlangga

F.R. Saputra, F.S. Rondonuwu, A. Sutresno .2013.Pemanfaatkan EkstrakAntosianinKolMerah (Brassica OleraceaVar) Sebagai Dye Sensitized dalamPembuatanPrototipe Solar Cell (DSSC),Seminar NasionalSainsdanPendidikanSains VIII4(1), 332-333,.

Harborne J.B. 2005.Phytochemical Methods New Delhi: Springer (India)Pvt.Ltd; p.17.

Harborne, J.B. 2006. MetodeFitokimia: Penuntun Cara Modern MenganalisisTumbuhan (alihbahasa: KosasihPadmawinata\&IwangSoediro).Bandung:Penerbit

ITB. 
UdanKusmawan, Afnidar, Srihamda, and DeetjeSunarsih/Enquiry Pedagogy in Teaching Titrations with using Natural Indicator

Hernandez, M. \& Joe, K. 2010.Development and Assessment of a Chemistry-Based ComputerVideoGameas a LearningTool, (Online), (http: //www. eric.ed. gov/ERICWebPortal/search/)

Liliasari. 2007. Scientific Concepts and Generic Science Skills Relationship inthe 21st Century Science Education. Seminar Proceeding of the First International Seminar of Science Education. 27 October 2007. Bandung. $13-18$

Maftuha, D.S. 2013. ImplementasiPemanfaatanIndikatorAlamiuntukPraktikum Kimia MateriPokokAsamBasasebagaiUpayaPeningkatanKeaktifandanPemahamanKonsepPesertaDidikkelas XI IPA MA AlMuttaqienPancasila Sakti KabupatenKelatenJawa Tengah, Skripi, Program Studi Kimia FakultasSainsdanTeknologi UIN SunanKalijagaYokyakarta.

Marwati S. 2011. KestabilanwarnaEkstrakKubisUngu (Brassica oleracea) sebagaiIndikatorAlamiTitrasiAsamBasa. Prosiding Seminar NasionalPenelitian, PendidikandanPenerapan MIPA FMIPA UNY, 11 Mei 2011

Marwati S. 2012. AplikasiBeberapaBungaBerwarnasebagaiIndikatorAlamiTitrasiAsamBasa. Prosiding Seminar NasionalPenelitian, PendidikandanPenerapan MIPA FMIPA UNY, 2 Juni 2012

SeafastCenter. 2012. Merah-UnguAntosianin, PewarnaAlamiuntukPangan (23-43)

Siahaan, L.O., Hutapea, E.R.F., Tambun, R. 2014. EkstraksiPigmenAntosianindariRambutan (Nepheliumlappaceum) denganPelarutEtanol, JurnalTeknik Kimia USU, 3(3), 32-38

Siti

Marwati.2010.

AplikasiBeberapaEkstrakBungaBerwarnasebagaiIndikatorAlamipadaTitrasiAsamBasa,

Prosiding

Seminar Nasional FMIPA UNY 2010. Yogyakarta: FMIPA UNY

Siregar, Y.D.I. 2015. PembuatanKertasIndikatorAsamBasadariBungaKembang Sepatu (Hibiscus rosasinensis), Program Studi Kimia FakultasSainsdanTeknologi UIN SyarifHidayatullah Jakarta.246-252.

Vogel 1994. BukuTeksAnalisisAnorganikKualitatifMakrodanSemimikro (Terjemahan), Jakarta: PT Kalman Media Pustaka

YustinaDewiNuritasari. 2010. UjiKecermatandanKeakuratanPenggunaanEkstrakKubisUngu (Brassica oleracea L) sebagaiIndikatorAlamiTitrasiAsamKuatBasaKuat.LaporanPenelitian, Yogyakarta: FMIPA UNY

Winarti, S., Sarofa, U., dan Anggrahini, D. 2008. Ekstraksi dan StabilitasWarnaUbiJalarUngu (Ipomoeabatatas L.,) sebagaiPewarna Alami, JurnalTeknikKimia, 3 (1), 207-214

RoestiyahNK.1985: 125, StrategiBelajarMengajar. BinaAksaraJakarta

$\begin{array}{llll}\text { Soeroso } & \text { AY., } & \text { Anna } & \text { Permanasari\&Kardiawarman. }\end{array}$

EnsiklopediSains\&KehidupanDepartemenPendidikanNasional 